\title{
Islamic Education and Colonial Education: Islamic School and Dutch School in Westkust Sumatra in Historical Perspective
}

\author{
Suriani $^{1}$, Kori Lilie Muslim ${ }^{2}$, Syaiful Anwar ${ }^{3}$, Melia Afdayeni $^{4}$, Salmi Wati ${ }^{5}$ \\ \{suriani@iainbukittinggi.ac.id ${ }^{1}$, korililiemuslim@iainbukittinggi.ac.id ${ }^{2}$, \\ syaifulanwar@fkipuisu.ac.id ${ }^{3}$, meliaafdayeni@iainbukittinggi.ac.id ${ }^{4}$, \\ salmiwati@iainbukittinggi.ac.id $\left.{ }^{5}\right\}$ \\ History of Islamic Civilization Department, Institut Agama Islam Negeri (IAIN) Bukittinggi, \\ Indonesia ${ }^{1,2,4}$ \\ Department of Historical Education, Islamic University of North Sumatera (UISU) Medan, Indonesia ${ }^{3}$ \\ Islamic Education Departement, Institut Agama Islam Negeri (IAIN) Bukittinggi, Indonesia ${ }^{5}$
}

\begin{abstract}
This paper aims to compare Islamic Educational and Colonial Education Institution in Westkust Sumatra from a historical perspective. It used the historical method by examining the literature on Islamic Education and Colonial Education in Westkust Sumatra. In the early 20th century, traditional Islamic educational institutions renewed themselves along with the renewal of Islam itself. Among them are Adabiyah School, Diniyah School, and Sumatra Thawalib. It's the strategy to compete with Colonial Educational Institutions which were considered as symbols of modern education. Islamic Education Institutions use different methods and curriculum from Colonial Education Institution. Islamic Educational Institutions use traditional method was called "halaqah" while Colonial Educational Institutions use modern method with table and chair. Although both of them are different, they were playing a major role in shaping the thinking of the indigenous and forming elite in Westkust Sumatra.
\end{abstract}

Keywords. Islamic Educational Institution, Colonial Education Institution, Westkust Sumatra

\section{Introduction}

Human Rights Issues, including the issue of education in the Western World in the late 19th century, brought a wave of criticism for the Dutch Colonial Government in its colonial country, the Dutch East Indies. They were bombarded and demanded to return the favor for everything they received from their colonies for hundreds of years. The demand arose because the Dutch Colonial Government did not treat the Indonesian people well, this was in line with what Multatuli had described in Max Havelaar's[1] novel, which was first published in 1860 in Dutch. The situation forced them to practice Ethical Politics - an idea put forward by C. Th. van Deventer- for the people of Indonesia in the early 20th century.

Ethical Politics with one of its programs, "education" became an achievement that the Dutch Indies Government was very proud of. This policy was greatly appreciated and well received by the people of the Dutch East Indies at that time, especially the Priyayi (aristocracy) 
group. They felt very grateful to the Dutch Government for the implementation of the policy. The implementation of this policy provides an opportunity for them to obtain a recognized education and expect a position of influence in the future in Government. Behind it all, the Ethical Politics policy was basically designed more for the benefit of the Netherlands Indies Government itself. Through Dutch schools built with the Western Education curriculum, there is a big plan, in addition to economic interests, which they compile. The big plan is to "western" the thinking of the Indonesian people. This "western" government was carried out to reduce the influence of Islamic Education which was very developed at that time. They are in very big concern. They considered Islam as a threat to the continuing power of the Dutch Indies Government in Indonesia.

The policy of the Dutch East Indies Government regarding Western Education follows Snouck Hurgronje's recommendation who has observed the way of life of the Dutch East Indies people directly in Aceh. He believed that Western education provided to the people of the colony would defeat the influence of Islam. Because in his view, the higher-natives of higher culture would be relatively far from the influence of Islam, while the influence they had would make it easier to reconcile it with European governments. Western education in its analysis is the most convincing means to reduce and ultimately conquer the influence of Islam in Indonesia. [2] A study of the policies imposed by the Government of the Dutch East Indies related to the education conducted by Syaidina Sapta Wilandra, he wrote that the government of the Dutch East Indies introduced association politics which subsequently got the reaction of Muslims Dutch East Indies.[3] Dutch schools began to be built throughout the Dutch East Indies, starting in Batavia which became the center of Government. There are four categories of schools namely: (1) European schools that fully use the Dutch State school model; (2) school for native people who use Dutch as the language of instruction; (3) schools for indigenous people who use regional / indigenous languages as the language of instruction; (4) schools that use the indigenous system.[4]

The emergence of Dutch schools does not necessarily get rid of existing Islamic Educational Institutions / Schools. Islamic Education Institutions have planted their roots deep enough, so it is very difficult to revoke. They only need to modify a little education system that they have applied so far so as not to compete with the Dutch School. Islamic organizations, such as Muhammadiyah, Nahdlatul 'Ulama, Jami'at Khair, Islamic Unity, Islamic Unity, alIrsyad, al-Washliyah, Tarbiyah Islamiyah Union responded quickly. They have special sections or sections in the context of establishing madrassas in various regions.[5] This happened also in Westkust Sumatra (Westkust Sumatra-Minangkabau) whose inhabitants - the Minang people were all followers of Islam. The study of Islamic Education in Minangkabau has been carried out by Azyumardi Azra. In his study, he specifically discusses Surau as a traditional Islamic educational institution that faces a period of transition and modernization.[6] Mahmud Yunus and Ramayulis have also carried out the dynamics of Islamic Education in Indonesia in general. This paper further synthesizes these writings and describes each of the Islamic education systems as well as the Colonial Education and its institutions.

\section{Islamic Education Institutions(Islamic Schools) In Westkust Sumatra}

The Islamic Education Institution in Westkust Sumatra - Minangkabau - had long existed, long before the Ethical Political Policy by the Netherlands Indies Government was implemented. The Educational Institution is Surau. Even before Islam entered Minangkabau, there was already a mosque. Raja Adityawarman once founded the Buddhist Surau complex 
around Bukit Gombak in 1356.[7] At that time the Surau was used as a cultural and traditional building which was also used as a Hindu-Buddhist ritual site. Surau is a place to study customs, deliberations and discuss things that can provide ideal solutions to problems that occur in society. Surau occupies an important social structure in the Minangkabau community. And after Islam entered, the Surau was not removed but functioned as a mosque in Islam. Since then, the mosque has become a symbol of religious Minangkabau society. Surau plays a role not only in matters relating to religion and education but also politics, customary economics and culture. Surau becomes an integral part of the collective memory of the Minangkabau people as a whole.

Surau as a traditional Islamic educational institution does not have class, formal bureaucracy and curriculum. The learning methods used are lectures, reading and memorization with halaqah models, learning models where students sit cross-legged around the teacher. Educational material taught in the mosque covers traditional education (traditional), including martial arts, literature, music, and dance as well as Petatah Petitih, also religious education related to the Qur'an, the Science of Fiqh and the practice of worship.[8]

Sheikh Burhanuddin was an important figure in the process of making the mosque as an Islamic educational institution. He founded the Surau in Ulakan at the end of the 17th century and became the carrier of the Sathariyah Order to Minangkabau. Since then, the mosque became a learning space for the Minangkabau people, especially Minang men. In fact, they make part of the mosque as their residence.[9] In addition to Sheikh Burhanuddin, there are also three Hajj, Poor Hajj, Sumanik Hajj, and Piabang Hajj, and Tuanku Nan Tuo and Tuanku Nan Renceh who use the mosque as a place for teaching and learning. They are part of the Paderi who intersect with the Indigenous Peoples.

Surau is an Islamic educational institution that lasted very long, until the beginning of the 20th century. During this period, this educational institution produced many figures who later played a role in the fields of education, politics, and economics in Indonesia. Among them are Mohammad Hatta and Agus Salim.

After that period, the traditional Islamic education system began to be modernized along with Islamic renewal in Minangkabau. Islamic renewal that occurred in Minangkabau has an important role in spreading the ideals of renewal to other areas.[10] Sheikh Ahmad Khatib Al Minangkabawi has a big role in the process of Islamic renewal in Minangkabau, even though he is not in Minangkabau. He is a Minang who settled in Mecca and became the Imam of the Grand Mosque. His influence reached Minangkabau through his pupils, who were also Minang, the Shaykh Muhammad Jamil Jambek in Bukittinggi, Dr. H. Abdullah Ahmad in Padang Panjang and Padang, Sheikh Muhammad Thalib Umar in Batu Sangkar, and H. Abdul Karim Amrullah at Maninjau.[6] Besides them there is also Syekh Sulaiman Ar-Rasuli, Zainuddin Labay el-Yunusi and Rahmah el-Yunusiah who are also important figures in the renewal of Islamic education in Minangkabau.[11]

Reform in Islamic Education has implications for the establishment of Islamic educational institutions in Minangkabau. This was also influenced by modernization brought by the Dutch Colonial Government. The figures mentioned earlier are the result of a mixed education system, a Dutch education system, and Dutch East Indies education. Therefore, the Islamic educational institutions they founded later had their own characteristics which is ready to be offered to the community.[12]

Haji Abdullah Ahmad founded the Adabiyah School in Padang Panjang in 1907. This school was the first modern Islamic Education Institute in Westkust Sumatra. In the learning process, Adabiyah School has used a blackboard, table, and bench.[11] This is what makes it different from how to study in Surau. However, these differences even get a reaction from the 
community who still support the traditional way of learning in Surau. The existence of these reactions and other reasons, causing the Adabiyah School did not last long and was forced to close.The closed Adabiyah School in Padang Panjang was re-established in Padang in 1909. The Adabiyah School was an educational institution in the form of a madrasa, so the material taught was Islamic religious material taught. However, the Adabiyah School was unable to maintain the purity of its "kemadrasahan" because it was subsidized by the Dutch East Indies Government. The Adabiyah School finally changed its name to the Hollandsh Malaiche School Adabiyah in 1915.[10] Adabiyah used the whole curriculum used by the Netherlands school it requires the school to teach religion and Al-Qur'an every week. It reaching and accreditation from the Government of Netherlands Other helps from the Netherlands was providing 3 teachers from the Netherlands and 1 headmaster 2 teachers in common.

In the same year, Zainuddin Labay el-Yunusi founded the Diniyah School in Padang Panjang. Diniyah School conducts educational reforms in several ways: (1) school learning system that is classical in nature, (2) learning material covering religious and general subjects, (3) the curriculum has been arranged regularly, (4) the school is oriented towards good quality outputs religious and general fields. Rahmah el-Yunusiah, the younger brother of Zainuddin Labay el-Yunusi subsequently founded Diniyah Putri on November 1, 1923, now known as Diniyah Putri Padang Panjang. In its implementation, Rahma applied two forms of education, formal and non-formal. Formal education is carried out in classrooms while formal education is carried out in a dormitory. Through these two systems, Rahma wants all her female students to be ready to become educators for their children.[11] Mother is the first madrasa in family basic education. The next Islamic Education Institution is Sumatra Thawalib which is the first modern Islamic school. This was originally an organization engaged in the field of education including two institutions namely Sumatra Thawalib in Padang Panjang and Sumatra Thawalib in Parabek. Then another Sumatran Thawalib school was established in Padang Panjang, in Sungayang Batusangkar, and Maninjau.[11] The Islamic Education Institution mentioned until now still exists by modifying its education system to keep pace with the times without eliminating its religion. In addition to these educational institutions, there are several other Islamic educational institutions that also have an influence on the development of Islamic education in Westkust Sumatra.

\section{Dutch School In Westkust Sumatra}

When the Dutch held power in Indonesia, there were various schools that were established for generations, both native and Dutch or other races. What's more when ethical politics scrolls. One of which is an ethical-political program is education. The colonial government established a school to run a program that was regarded as political retaliation against the colony. The schools which were established in the Dutch East Indies in the past are far from the system of retaliation that was heard by the colonial government. The problem is that there is a wide gap against people (between the indigenous and the Dutch) who attend school there. For elementary school (SD), there are two schools, namely Hollandsche Inlandsche School (HIS) and Europesche Lager School (ELS). Both have basic differences, the HIS is populated by indigenous people, while ELS is filled by the majority of the Dutch or European people in general. Although HIS School is reserved for the indigenous peoples, it is not immediately any person can attend school, because there is a special requirement to get into the schools, the income of parents who should be 100 gulden per month. For the record, revenue of 100 gulden 
in the colonial period was the upper or the nobility. While in ELS though reserved for European people, it can also be filled by the native circles with the record of indigenous authorities. Uniquely, although the two schools use Dutch as the language of instruction, the colonial government never required the entire resident of the colony to be the language.[13]

They are the characteristic of elementary school form that is found in the Dutch East Indies or before Indonesia is independent. However, besides the two schools apparently, there are similar schools that have been cultivated by the natives, namely Indonesisch Nederlandsche Scholl (INS) Kayutanam. Even INS is one of the flagship schools located in Padang Pariaman Regency, Westkust Sumatera.

In 1926 INS was founded by Muhammad Sjafei. The purpose of this school was established as a distinct alternative to the Islamic school's rivalry with the Dutch colonial education. One characteristic of the INS is to liberate his disciples to think as wide as he is. Of course, this trait is much different between Islamic education and Dutch colonial education. Therefore, some sources declare INS too bold with such an educational model. However, it has spawned many of the major figures we know today, such as Tarmidtaher, Ali Akbar Navis, Mochtar Lubis, Hasnan Habib, and Kaharuddin Nasution.

INS is however also only one of the other schools located in Westkust Sumatera. It is difficult to give a comparison especially to schools established by the colonial government. Kweekschool as the earliest Dutch teacher school was the focus of the community in general. Established in 1856 in Bukittinggi, Kweekschool first produced teachers for Nagari schools in Westkust Sumatera. INS which started in 1926 could not miss the role of Kweekschool in fulfilling the teachers needed. Therefore, the model of freedom of thought or other alternatives from the competition of Islamic Education and colonial education, Soko Guru is still initiated by Kweekschool. The role of Islam is also insignificant in the development of INS Kayutanam.

The Colonial Education system and its institution in Westkust Sumatera in the colonial era is quite good when compared with other areas in Sumatra. Although not as good as in Java, the development of education in Westkust Sumatera especially in Western education is quite capable of providing adequate service. Kweekschool in Bukittinggi is the most prestigious school in the colonial period. But other schools are also very concerned and growing. Since the beginning of the 20th century, in Bukittinggi alone there have been low schools such as Volkschool, HIS, and MULO. Even Bukittinggi is the most place in the education of all Westkust Sumatera. Perhaps from then until now, Bukittinggi is known as the city of Education. A pretty good degree of education does not mean to be separated from criticism. Van der Chijs in 1872 began to show that between the Nagari school and Kweekschool had the same curriculum.[8] He proposed a standard curriculum on how Kweekschool should run. With the decree of Governor-General No. 275 then made qualifications: The chief teacher is a Dutch; Second teacher was also a Dutch; As well as the third teacher who was a Dutch; Then there was a man or a few Malay teachers. This standard was done at Kweekschool in Bukittinggi so that the colonial aura is increasingly felt in the implementation of education.

To qualify for the second teacher, it must have the Hofdonderwijs deed. Malay language is used to write, read, and Count. While the subjects taught were Dutch, Malay, numeracy, earth science, and Tambo were from the Dutch East Indies, the Netherlands, and Europe.

In addition to Kweekschool, MULO (Meer Uitgebreid Lager Onderwijs) is an advanced school that was present in the colonial era in Westkust Sumatera. Almost the same as the one in Java, MULO was established to accommodate graduates of Kweekschool and ELS who want to continue the study. In Westkust Sumatera, MULO is also located in Bukittinggi, which stood in 1933. The MULO language course consists of 4 kinds: Dutch, French, English, and German. Half of all subjects at the MULO are language subjects. Another third for the subjects of 
mathematics and natural sciences, and one-sixth for social science.[14] The duration of the student study at the MULO is for 3 years, plus 1 year which is the transition period to HBS. Students who complete the MULO can continue their education to a higher level such as HBS, AMS, and vocational schools. The famous Minang people who came from the MULO graduates are quite a lot. Among them are Muchtar Luthfi, Ijas Jacub, Djamaluddin Thaib, Djamaludin Ibrahim, Rasuna Said, Chatib Sulaiman, Darwis Thaib, or Leon Salim. Of these graduates went to high school in Java and abroad such as the Netherlands.[15]

\section{Islamic Education and Colonial Education: The Changes In Westkus Sumatra}

Islamic education and colonial education, both brought about the change in Westkust Sumatera. A very pronounced change is in the realm of politics. Since the founding of Islamic schools and Dutch schools, the extensive open-air school opportunities for the community led to the emergence of politicians whose thoughts were to color the dynamics of politics in the Westkust of Sumatra.

The development of education in Westkust Sumatera has a direct impact on the mindset of society. Young people and the elderly have a big difference in looking at life. Selian's culture, religion, and modern thinking color every social relationship that exists, and not infrequently have a conflict between the two, whether it is religious education as well as getting a Western education. Looking at the growing education in Westkust Sumatera then it can indirectly see its role in the development of the country itself, especially in the early days of movement and independence. Westkust Sumatera is the region that contributes the most thinkers and founding fathers to this nation. Call it some of them like Moh. Hatta, Sutan Syahrir, H. Agus Salim, Tan Malaka and many more who have occupied the cabinet in the old order era. It is still not added by poets such as Chairil Anwar or literary writers such as Hamka, A.A. Navis and so on. Of course, this can not be separated from the development of education in the Westkust Sumatera which has a great effect on the change to the nature of Minang itself as well as for all of Indonesia. The most influential education in scoring young intellectuals in the early days of independence is the INS as mentioned above. Figures such as A.A. Navis and Mochtar Lubis are Jebolah INS. The influence in the field of Sastra Indonesia is quite large. This can happen due to the concept of the INS school itself that emphasizes freedom. According to Gusti Asnan, the free pattern of thinking can stimulate his students to be more creative.

The Western education system organized by the Dutch East Indies government since the middle of the 19th century in Minangkabau has a large impact on the community mindset of the indigenous. Western education resulted in the emergence of new strata in the community, namely the learned people who have high social status in the community in addition to the scholars, indigenous leaders, and traders who are wealthy.

The presence of modern educational institutions in Minangkabau not only affects the introduction and absorption of ideas about modernization by the community, which impacts social, political and economic life. There is a cultural-ideological mobility that includes the open opportunities of vertical mobility in the community. One of them is through a position opportunity in the government bureaucracy. The impact on the economy is the absorption of employment in various fields. On the other hand, Surau begins to be seen as increasingly irrelevant to the needs of the times. With the development of Dutch education, there is a change 
of community mindset that teachers, doctors, prosecutors and position positions in the government is more prestigious in society.

Further response from Western education in Westkust Sumatera is community segmentation. Although Western education is open, there are also rejecting or apathy. It generally raises three groups in society. First, the group agrees with the existence of Dutch schools, as it gives the opportunity of new social status, position and positions in the government. The group consists of a group of local leaders affiliated with the colonial government and a group of traders who have an above-average income. Secondly, the group who refused because it was considered able to change the tradition in Minangkabau, which is a group of indigenous leaders who do not want to be affiliated with the Government, the indigenous groups are relatively small. Thirdly, the apathy group is a group consisting of farmers who have a lot of land so busy working in gardens and rice fields.[8] This group is not very interested in school development because it is predicated with plantation activities that are hereditary. The Dutch East Indies colonial government gave the Bumiputera the opportunity to sit in the government on the condition of having pursued a basic education that was applied by the colonial. For government education organizing based on ethical politics can fill the places that do need labor. In other words, indirectly, Western education also became the door to the exploitation of labor effectively with the ability to write and read. While in the community, education and occupation with the colonial government can precisely raise the status and degrees in the midst of society.

In the implementation of education, there is the division of caste; That not all local communities can study in schools formed by the colonial government. For the indigenous leaders or the nobility can easily enter the colonial government-made school. Likewise with wealthy traders. However, for most people admission to the colonial government schools is almost impossible. Uniquely, the economic status in Westkust Sumatera can be said enough for the average community. Therefore, there are many indigenous people who can be educated. When the colonial government ruled until the inclusion of Japan, Westkust Sumatera was the most educated area compared to other places in Indonesia.

Children who receive colonial education usually grow into intellectuals who act as intermediaries between indigenous peoples and religions. The group was a new group that was present when Western education was in Westkust Sumatera. The intellectuals emerged between indigenous and religious domination since the early 19th century. As an intermediary, intellectuals often try to withdraw to both indigenous and religious groups. The community considers that intellectuals are more educated, modern, and knowledgeable, but are deemed incomplete if they do not represent religion or custom.

The learner is permissive to education and this can affect young people to attend school. Given that there is no high school in Westkust Sumatera, the students continue their studies to Java. In the period 1874-1900, a total of 7 of the 183 Minangkabau children signed up for the STOVIA (native Doctor's school) in Batavia. In the period 1900-1914, STOVIA over 36 of its 200 students came from Minangkabau.[16]

\section{Conclusion}

Islamic Education and Colonial Education are two educational systems that have different goals. Islamic education system has long existed, even since the $17^{\text {th }}$ century. Meanwhile, the colonial education system began to be applied in the Dutch East Indies in late $19^{\text {th }}$ century to 
the early $20^{\text {th }}$ century. However, colonial education was a direct symbol of modern education, while Islamic education became an expansion. Islamic education is considered as a traditional educational system so that Islamic education institutions begin to lose their fans. Colonial education through his education institutions has laid the minds and lifestyles of the Dutch East Indies community, including Westkust Sumatera. It became a concern for the Islamic community in Westkust Sumatera. To overcome this, Islamic education institutions took the strategy to renew their education system. He adopted the colonial education system without leaving any important substance, religious education, moral and customs to be able to survive in competition with colonial education institutions

\section{References}

[1] Multatuli, Max Havelaar of The koffij-velingen der Nederlandsche Handel-Maatschappij. Amsterdam, 1868.

[2] H. Aqib Suminto, Politik Islam Hindia Belanda. Jakarta : LP3ES, 1985.

[3] S. S. Wilandra, "Politik Asosiasi Pendidikan Pemerintah Hindia Belanda," 2019. [Online]. Available: https://jejakislam.net/politik-asosiasi-pendidikan-pemerintah-hindia-belanda/. [Accessed: 18-Sep-2019].

[4] V. Horohiung, "Pendidikan Formal Era Hindia Belanda di Kepulauan Sangihe Pada tahun 1848 1945," Pendidikan. Sej., vol. 5, no. 2, 2016.

[5] M. Yunus, Sejarah Pendidikan Islam di Indonesia. Jakarta: Mutiara Sumber Widya, 1995.

[6] A. Azra, Surau : Pendidikan Islam Tradisional dalam Transisi dan Modernisasi. Jakarta: Logos, 2003.

[7] S. Gazalba, Masjid : Pusat Ibadah dan Kebudayaan Islam. Jakarta: Pustaka Antara, 1975.

[8] I. Fansuri Mursal, "Surau dan Sekolah: Dualisme Pendidikan di Bukittinggi," Titian J. Ilmu Hum., vol. 2, no. 1, p. 100, 2018.

[9] A. Abdullah, "Perkembangan Pesantren Dan Madrasah Di Indonesia Dari Masa Kolonial Sampai Orde Baru," Paramita, vol. 23, no. 2, 2013.

[10] D. Noer, Gerakan Modern Islam di Indonesia 1900-1942. Jakarta: LP3ES, 1996.

[11] R. Rahman, "Modernisasi Pendidikan Islam Awal Abad 20 (Studi Kasus di Sumatera Barat)," Humanis, vol. XIV, no. 02, p. 174, 2015.

[12] Ramayulis, Sejarah Pendidikan Islam. Jakarta: Kalam Mulia, 2012.

[13] P. Matanasi, "Sekolah-sekolah di Zaman Belanda," 2016. [Online]. Available: https://tirto.id/sekolah-sekolah-di-zaman-belanda-bXbV. [Accessed: 18-Sep-2019]

[14] S. Nasution, Sejarah Pendidikan Indonesia. Jakarta : Bumi Aksara, 1994.

[15] A. Kahin, Dari Pemberontakan ke Integrasi, Sumatera Barat dan Politik Indonesia 1926-1998. Jakarta: Yayasan Obor Indonesia, 2005.

[16] T. Kato, Adat Minangkabau dan Merantau dalam Perspektif Sejarah. Jakarta: Balai Pustaka, 2005. 